\title{
Using Teaching Portfolios to Revise Curriculum and Explore Instructional Practices of Technology and Engineering Education Teachers
}

\author{
Michal Lomask, David Crismond, \& Michael Hacker
}

\begin{abstract}
This paper reports on the use of teaching portfolios to assist in curriculum revision and the exploration of instructional practices used by middle school technology and engineering education teachers. Two new middle school technology and engineering education units were developed through the Engineering for All (EfA) project. One EfA unit focused on addressing world food shortages via the design and construction of urban vertical hydroponic farming systems, and the other focused on providing safe drinking water through the design and construction of water filtration and purification systems (modeled to reflect needs of people in a developing nation, in this case, Bangladesh). To explore the implementation of the new EfA units by teachers and to help with their revision, a new teaching portfolio instrument was developed, validated, and used. The teaching portfolios that participating EfA teachers compiled were evaluated based on a set of Design Teaching Standards that were developed for the project, and which grew out of the informed design teaching and learning model. Findings from the review of the teaching portfolios were used to (a) revise the curriculum, (b) create design-based teaching performance rubrics, and (c) develop specific materials for the professional development of prospective EfA teachers. Findings from this research project were also used to explore the strengths of middle school technology and engineering teachers and the challenges that they face when supporting students in doing engineering design in a social context.
\end{abstract}

Keywords: Teaching portfolios, technology and engineering education, instructional practices, design-based teaching standards.

The Engineering for All (EfA) project was a five-year-long collaboration between Hofstra University and the International Technology and Engineering Educators Association (ITEEA), and was funded by the National Science Foundation's DRK-12 program. ${ }^{1}$ The main goal of this project was to develop middle school technology and engineering (T\&E) education units that emphasize the role of engineers in solving important global and communitybased problems. The project developed two units that contain authentic design

\footnotetext{
${ }^{1}$ This material is based upon work supported by the National Science Foundation under Grant No. 1316601.
} 
challenges appropriate for the experiences and capabilities of middle school students. The two developed units dealt with the global shortage of fresh food and clean water. Both challenges were cited as priorities for integration into technology education curriculum (Buelin, Clark, \& Ernst, 2016) and related to the Grand Challenges for Engineering identified by the National Academy of Engineering (NAS, 2017). One unit, Vertical Farming: Fresh Food for Cities, is focused on the development of sustainable food sources for cities through the inclusion of urban vertical hydroponics farms. The second unit, Water: The World in Crisis, is focused on the development of water filtration systems to be used in countries afflicted with contaminated water sources. Both units incorporate the "informed design" curricular structure (Burghardt \& Hacker, 2004), which first introduces students to the major design challenge, followed by a "progression of knowledge and skill builders (KSBS)" (p. 7), activities that provide the students with the prerequisite experiences, knowledge, and skills to deal with the design challenge from a STEM-informed knowledge and skill base with the aim of reducing the uses of craft-based and trial-and-error approaches to solving design challenges.

The units were developed by T\&E teacher teams, led by experienced curriculum developers, and were subsequently tested by 22 middle school T\&E teachers and 755 students. As preparation for testing the units, the teachers participated in professional development workshops in which they learned the content and tried out the hands-on activities included in the two EfA units. During a pilot study of the new units, participating teachers constructed teaching portfolios that contained a structured weekly log and student work. In addition, the teachers participated in monthly WebEx phone conferences in which they reported on specific challenges in implementing the curriculum. Based on these conversations and data gathered during the pilot study, the units were revised and improved, making them more accessible to both teachers and students. The curriculum materials are available from ITEEA.

The following sections include descriptions of the development of the project's instruments, including: EfA Design Teaching Standards, EfA Design Teaching Portfolio, and the EfA Design Teaching Performance Rubrics.

EfA Design Teaching Standards

Knowing how to teach engineering involves quite a different knowledge and skill set than knowing how to do engineering. Like engineers, teachers using design tasks need to have content knowledge and process skills, but they also need pedagogical content knowledge (PCK), which is domain-specific and contextualized to each content area (Ball, Lubienski, \& Mewborn, 2001; Magnusson, Krajcik, \& Borko, 1999; Shulman, 1986). The Design Teaching Standards (DTS) were developed to describe this elusive PCK by defining what middle school T\&E teachers need to know and be able to do in order to support students' learning with design-based curriculum. Because there were no 
published teaching standards for the teaching of $\mathrm{K}-12$ engineering design in the United States, the EfA research team had to develop these standards to guide the work of the participating teachers. The development of the Design Teaching Standards was informed by the scholarly experiences in science and technology education of the three authors. Other sources that informed the development process include the Minimum Competences for Trainees to Teach Design and Technology in Secondary Schools in the UK (Design and Technology Association, 2003), the Standards for Preparation and Professional Development for Teachers of Engineering (American Society for Engineering Education, 2014), the National Science Education Standards (National Research Council, 1996) in the United States, and frameworks for engineering design teaching and learning (Crismond \& Adams, 2012; Cross, 2000; Hacker, 2014; Reimers, Farmer, \& Klein-Gardner, 2015).

The final set of the EfA DTS (see Table 2) created for this project is organized around the following three dimensions.

- Dimension I: Design Practices - This standard describes different practices that are part of the "informed design" teaching.

- Dimension II: Engineering Themes-This standard identifies crosscutting themes and concepts that consistently appear in the engineering design literature (i.e., design, modeling, systems, resources, and human values).

- Dimension III: Classroom Instructional Practices-This standard describes essential instructional practices that are commonly considered necessary to support student learning.

The DTS were examined and validated by $\mathrm{K}-12$ science, engineering and technology education teachers, teacher trainers, curriculum developers, STEM education researchers, administrators, and policy makers. Some participants were asked to comment on the quality of the standards in face-to-face interviews, whereas others completed an online questionnaire. In this online survey, the educators were asked to read each standard and rate their level of agreement with the following statements.

- Survey Statement 1: "The standard is feasible for teaching in the technology classroom."

- Survey Statement 2: "The standard is important for teaching engineering design."

- Survey Statement 3: "The standard is clearly written."

Statements were rated on a 5-point Likert scale from strongly disagree (1) to strongly agree (5).

Table 1 summarizes the results of the online validation survey of the DTS. As can be seen in Table 1, most of the 38 survey participants agreed that the standards are instructionally feasible (93\%), important (97\%), and clearly written (92\%). These results add validity to the EfA Design Teaching Standards. 
Table 1

Results from the Online Validation Survey of the DTS

\begin{tabular}{lccc}
\hline & \multicolumn{3}{c}{ Percent agreement with survey statement ${ }^{\text {a }}$} \\
& \multicolumn{3}{c}{$(\mathrm{n}=38)$} \\
\cline { 2 - 4 } & $\begin{array}{c}\text { Standards are } \\
\text { feasible for } \\
\text { classroom } \\
\text { teaching }\end{array}$ & $\begin{array}{c}\text { Standards are } \\
\text { important for } \\
\text { teaching } \\
\text { engineering } \\
\text { design }\end{array}$ & $\begin{array}{c}\text { Standards are } \\
\text { clearly written }\end{array}$ \\
\hline $\begin{array}{l}\text { I. DTS dimension } \\
\begin{array}{l}\text { II. Engineering } \\
\text { Themes }\end{array}\end{array}$ & $92 \%$ & $98 \%$ & $94 \%$ \\
$\begin{array}{l}\text { III. Classroom } \\
\text { Instruction }\end{array}$ & $94 \%$ & $96 \%$ & $88 \%$ \\
\hline $\begin{array}{l}\text { Mean \% for all } \\
\text { dimensions }\end{array}$ & $93 \%$ & $97 \%$ & $94 \%$ \\
\hline
\end{tabular}

${ }^{a}$ Includes the combined responses of agree (4) and strongly agree (5).

Table 2

The EfA Design Teaching Standards

\begin{tabular}{ccc}
\hline Dimension I: & Dimension II: & Dimension III: \\
Informed Design & Engineering Themes & Classroom Instruction \\
Practices &
\end{tabular}

\begin{tabular}{|c|c|c|}
\hline $\begin{array}{l}\text { When teaching } \\
\text { engineering design, } \\
\text { teachers facilitate } \\
\text { students' development of } \\
\text { engineering design } \\
\text { thinking and practices. } \\
\text { In doing this, teachers } \\
\text { provide students with } \\
\text { opportunities to: }\end{array}$ & $\begin{array}{l}\text { When teaching } \\
\text { engineering design, } \\
\text { teachers facilitate } \\
\text { students' learning of } \\
\text { engineering themes. } \\
\text { In doing this, teachers } \\
\text { provide students with } \\
\text { opportunities to: }\end{array}$ & $\begin{array}{l}\text { When teaching } \\
\text { engineering design, } \\
\text { teachers use } \\
\text { appropriate } \\
\text { instructional strategies } \\
\text { to engage and monitor } \\
\text { the learning of all } \\
\text { students. } \\
\text { In doing this, teachers: }\end{array}$ \\
\hline $\begin{array}{l}\text { Framing the } \\
\text { Challenge: } \\
\text { Understand and } \\
\text { frame the design }\end{array}$ & $\begin{array}{l}\text { a. Design: } \\
\text { Use knowledge, } \\
\text { creativity, critical } \\
\text { thinking and ethics }\end{array}$ & $\begin{array}{l}\text { a. STEM Concepts: } \\
\text { Integrate and } \\
\text { explain science, } \\
\text { technology, }\end{array}$ \\
\hline
\end{tabular}


challenge by identifying and specifying the expected design performances, criteria and constraints.

b. Doing Research: Conduct research and use inquiry methods to gather relevant information about the challenge.

c. Generating Alternatives:

Brainstorm a range of possible design solutions and use drawings or other graphics, when appropriate, to represent these ideas.

d. Making decisions: Balance pros/cons and consider tradeoffs in choosing the optimal solution. when exploring and developing informed design solutions.

b. Models:

Use a variety of modeling techniques to envision solutions, develop explanations and make predictions.

c. Systems:

Use systems

thinking to analyze the inputs, processes, outputs, controls and feedback loops of a product and its subsystems.

d. Resources: Understand the need to choose resources based on availability, appropriateness, cost, ease of use, and sustainability. engineering and mathematics

(STEM) content concepts that are relevant to the design challenge.

b. Lesson Plans: Set appropriate learning goals and adjust curricula to create lessons that address students' specific learning needs.

c. Academic

Learning:

Incorporate literacy, numeracy and information technology to advance students' design thinking and work.

d. Practical

Learning:

Ensure the safe, efficient and skillful use of materials and tools by all students. 
e. Prototyping:

Create prototypes based on plans of possible solutions selected for testing.

f. Testing:

Design and perform tests to determine how the prototypes work and how well they meet design criteria.

g. Iterating and Improving: Use feedback from tests and ideas from others to refine and improve prototype.

h. Communicating and Reflecting:

Reflect on and share with peers the design work, the processes used and decisions made. e. Needs, Impacts, \& Human Values:

Explore and consider the design context, users' needs and values, and the impacts of the design solution on the environment. e. Team Work: Encourage students to work collaboratively and share ideas and resources with peers.

f. Assessments:

Use assessments to gather evidence of students' learning and provide timely feedback.

\section{EfA Design Teaching Portfolios}

Teaching portfolios have been used by educators for more than two decades. Teaching portfolios that include student work and teachers' reflections capture the complexities of the teaching practice better than written tests or classroom observations. Not only are portfolios an effective way to assess teaching quality, but they also provide teachers with unique opportunities for self-reflection and collegial interactions based on documented episodes of their own teaching. (Wolf, 1996, p. 34)

Typically, teacher portfolios are used as a tool for teacher evaluation. For example, teacher portfolios were used by the Connecticut State Department of 
Education for 2 decades for the evaluation and support of beginning school teachers (Lomask, Pecheone, \& Baron, 1995). Teaching portfolios are also used by the National Board for Professional Teaching Standards (Darling-Hammond, 1999) as a major component of their comprehensive assessment of quality teaching. Lately, many states have adopted the teaching portfolio, as in the edTPA national project, as a tool to assess the quality of preservice teacher performance (Sato, 2014). In all of these examples, the portfolios were designed to gather authentic data in order to evaluate the quality of the teachers.

During the EfA project, teaching portfolios were selected and primarily used to review and gather data about the implementation of the new curricula and about common instructional practices of the participating teachers. In addition, the portfolios were employed by the research team as a way to provide ongoing feedback to the developers of the two EfA units and as a source of materials for future professional development. For example, copies of student work and classroom videos from submitted portfolios became part of the training materials for interested teachers at the 2016 ITEEA national conference held in National Harbor, Maryland. The main entries in the EfA teaching portfolio are described in Figure 1.

EfA teaching portfolio entries and required materials:

1. Instructional logs written at the end of each KSB (5-6 entries per unit of instruction). These logs address the following issues:

a. Main STEM concepts that were taught,

b. Main engineering practices that were practiced by students,

c. Findings about students' learning strengths and challenges during each $\mathrm{KSB}$, and

d. Challenges in teaching each instructional sequence within the EfA unit.

2. Student work from one male and one female student, done to complete each of the KSB's formative assessment tasks. Student work was reviewed and evaluated by each participating teacher.

3. Three unedited instructional video clips, each 5-10 minutes in length, and selected to depict the following:

a. Teaching a STEM concept,

b. Teaching an engineering design practice, and

c. Students' oral presentations of their final project with oral feedback from the teacher.

4. Written reflection on the implementation of the curriculum and what revisions may be needed in order to improve the unit and enhance student learning.

Figure 1. An overview of the EfA Design Teaching Portfolio. 


\section{EfA Teaching Performance Rubrics}

The development of the teaching performance rubrics was an iterative process in which portfolios were reviewed by three professional technology and science educators in light of the evolving DTS. The rubrics were designed to provide a framework for the research about teachers' design PCK and to provide feedback to the curriculum developers. Since the rubrics were not used for formal teacher evaluation, no attempt was done to explore the reliability of the rubrics as a scoring tool. Rather, the portfolio reviewers worked collaboratively to develop the rubrics and then applied them in their review of the submitted teachers' portfolios. Tables 3, 4, and 5 describe the three EfA Design Teaching Performance Rubrics, one for each of the DTS dimensions.

Table 3

EfA Teaching Performance Rubrics: Design Practices

\begin{tabular}{|c|c|c|c|c|}
\hline \multicolumn{2}{|c|}{$\begin{array}{c}\text { Dimension I: } \\
\text { Design Practices }\end{array}$} & \multirow{2}{*}{$\begin{array}{l}\text { Advanced } \\
\text { Teacher helps students } \\
\text { grasp the design } \\
\text { challenge and its } \\
\text { context, as well as the } \\
\text { criteria and constraints } \\
\text { for a successful design } \\
\text { solution. }\end{array}$} & \multirow{2}{*}{\begin{tabular}{l}
\multicolumn{1}{c}{ Progressing } \\
Teacher describes the \\
design challenge and \\
its context, as well as \\
the criteria and \\
constraints for a \\
successful design \\
solution.
\end{tabular}} & \multirow{2}{*}{$\begin{array}{l}\text { Novice } \\
\text { Teacher describes the } \\
\text { design challenge and } \\
\text { reviews with the } \\
\text { students the design } \\
\text { criteria and constraints. }\end{array}$} \\
\hline a. & $\begin{array}{l}\text { Framing the } \\
\text { Challenge }\end{array}$ & & & \\
\hline b. & $\begin{array}{l}\text { Doing } \\
\text { Research }\end{array}$ & $\begin{array}{l}\text { Teacher requires } \\
\text { students to conduct } \\
\text { research and hands-on } \\
\text { investigations to gather } \\
\text { relevant data on the } \\
\text { design challenge. }\end{array}$ & $\begin{array}{l}\text { Teacher requires } \\
\text { students to gather data } \\
\text { on the design } \\
\text { challenge, mainly } \\
\text { through reading of } \\
\text { relevant materials. }\end{array}$ & $\begin{array}{l}\text { Teacher does not } \\
\text { require students to } \\
\text { gather relevant data } \\
\text { before they start } \\
\text { working on the design } \\
\text { challenge. }\end{array}$ \\
\hline c. & $\begin{array}{l}\text { Generating } \\
\text { Alternatives }\end{array}$ & $\begin{array}{l}\text { Teacher encourages } \\
\text { students to develop } \\
\text { several different } \\
\text { possible solutions to } \\
\text { the design challenge. }\end{array}$ & $\begin{array}{l}\text { Teacher encourages } \\
\text { students to develop } \\
\text { two different possible } \\
\text { solutions to the design } \\
\text { challenge. }\end{array}$ & $\begin{array}{l}\text { Teacher accepts one } \\
\text { possible solution early } \\
\text { in the design process. }\end{array}$ \\
\hline d. & $\begin{array}{l}\text { Making } \\
\text { Decisions }\end{array}$ & $\begin{array}{l}\text { Teacher asks students } \\
\text { to discuss the benefits } \\
\text { and tradeoffs of the } \\
\text { different solutions and } \\
\text { to justify their } \\
\text { selection of the } \\
\text { solution they would } \\
\text { develop into a } \\
\text { prototype. }\end{array}$ & $\begin{array}{l}\text { Teacher asks students } \\
\text { to justify their } \\
\text { selection of the } \\
\text { solution they would } \\
\text { develop into a } \\
\text { prototype. }\end{array}$ & $\begin{array}{l}\text { Teacher allows students } \\
\text { to develop their chosen } \\
\text { solutions into a } \\
\text { prototype without } \\
\text { explaining their design } \\
\text { decisions. }\end{array}$ \\
\hline e. & Prototyping & $\begin{array}{l}\text { Teacher provides } \\
\text { students with basic } \\
\text { safety guidelines for }\end{array}$ & $\begin{array}{l}\text { Teacher provides } \\
\text { students with basic } \\
\text { safety guidelines for }\end{array}$ & $\begin{array}{l}\text { Teacher provides } \\
\text { students with basic } \\
\text { safety guidelines for the }\end{array}$ \\
\hline
\end{tabular}


the use of materials and tools, and helps students achieve high standards of safety and craftsmanship.

f. Testing and Improving

Teacher asks students to test, document and evaluate the performance of the prototypes based on the given design criteria.

\section{Teacher provides} students with time and materials to revise their prototypes based on evidence they collected during testing.

h. Communicating and Reflecting the use of materials and tools, and makes sure students follow the guidelines.

Teacher asks students to test and documen the performance of the prototypes they develop.

Teacher provides students with time and materials to revise and improve their prototypes.

Teacher requires students to present their design work but doesn't provide them with formative feedback. use of materials and

tools.

Teacher doesn't require students to conduct tests of the performance of their prototypes.

Teacher doesn't require students to revise and improve their prototypes.

Teacher doesn't require students to present their design work.

\section{Table 4}

EfA Teaching Performance Rubrics: Engineering Themes

\begin{tabular}{cl}
$\begin{array}{c}\text { Dimension II: } \\
\text { Engineering } \\
\text { Themes }\end{array}$ & \multicolumn{1}{c}{ Advanced (5) } \\
\hline a. Design & $\begin{array}{l}\text { Teacher enables } \\
\text { students to do informed } \\
\text { design thinking by } \\
\text { supporting their use of } \\
\text { concepts, practices, } \\
\text { creativity, critical } \\
\text { thinking and ethics } \\
\text { when engaging in } \\
\text { design challenges. }\end{array}$
\end{tabular}

b. Models
Teacher encourages students to use drawings and models during the design process, and to discuss the models' strengths and limitations
Progressing (3)
Novice (1)

Teacher encourages selected aspects of informed design thinking, including students' use of concepts, practices, creativity, critical thinking and ethics when engaging in design challenges.

Teacher encourages students to use drawings and models during the design process.
Teacher provides limited or no time for students' use of concepts, practices, creativity, critical thinking and ethics when designing.

Teacher provides limited exposure to the use of drawings and models when designing. 
in representing more complex products and systems.

c. Systems Teacher helps students to identify subsystems and the inputs, processes, and outputs in their designed system and to distinguish between open and closed-loop systems.

d. Resources Teacher helps students to explore the need to choose resources based on availability, appropriateness, cost, ease of use, and sustainability when making their design choices.

e. Needs, Teacher encourages Impacts, students to explore how and

Human

Values the designed product may impact intended users and the environment.
Teacher helps students to identify subsystems and the inputs,

processes, and outputs in their designed system.

Teacher reviews the availability of resources and their use when making design decisions.

Teacher encourages students to pay attention to the needs of those who will use the designed product.
Teacher helps students to identify the parts that work together and makeup their designed system.

Teacher offers little or no support to students for considering the selection and rationales for use of particular resources.

Teacher provides limited attention to the design context and the users of the designed product.

Table 5

EfA Teaching Performance Rubrics: Classroom Instruction

\section{Dimension III: \\ Classroom \\ Instruction}

STEM
Advanced

Teacher accurately explains and connects all the relevant STEM concepts to the design challenge.

b. Lesson Plans
Teacher adapts the learning activities or creates new ones, and uses a variety of instructional strategies to accommodate the learning needs of all students in class.
Teacher accurately explains some of the design-relevant STEM concepts.

Teacher changes the pace and/or sequence of the learning activities in the given curriculum to accommodate students in class.
Novice

Teacher either does not explain relevan STEM concepts or makes mistakes when explaining these concepts.

Teacher teaches the given curriculum without any adaptations to the learning needs of students in class. 


\begin{tabular}{|c|c|c|c|c|}
\hline c. & $\begin{array}{l}\text { Academic } \\
\text { Learning }\end{array}$ & $\begin{array}{l}\text { Teacher provides } \\
\text { students with activities } \\
\text { that require them to } \\
\text { apply literacy and } \\
\text { numeracy skills and } \\
\text { provides them with } \\
\text { specific feedback on } \\
\text { their performance. }\end{array}$ & $\begin{array}{l}\text { Teacher provides } \\
\text { students with activities } \\
\text { that require them to } \\
\text { apply literacy and } \\
\text { numeracy skills. }\end{array}$ & $\begin{array}{l}\text { Teacher does not use } \\
\text { activities that require } \\
\text { application of literacy } \\
\text { and numeracy skills. }\end{array}$ \\
\hline d. & $\begin{array}{l}\text { Practical } \\
\text { Learning }\end{array}$ & $\begin{array}{l}\text { Teacher demonstrates } \\
\text { the safe, correct and } \\
\text { efficient use of tools, } \\
\text { materials, and } \\
\text { equipment and ensures } \\
\text { that all students follow } \\
\text { the required safety } \\
\text { protocols and } \\
\text { regulation. }\end{array}$ & $\begin{array}{l}\text { Teacher demonstrates } \\
\text { the safe use of tools, } \\
\text { materials, and } \\
\text { equipment and ensures } \\
\text { that all students follow } \\
\text { the required safety } \\
\text { protocols and } \\
\text { regulations. }\end{array}$ & $\begin{array}{l}\text { Teacher ensures that } \\
\text { all students follow the } \\
\text { required safety } \\
\text { protocols and } \\
\text { regulations. }\end{array}$ \\
\hline e. & $\begin{array}{l}\text { Team } \\
\text { Work }\end{array}$ & $\begin{array}{l}\text { Teacher encourages } \\
\text { teamwork and sharing } \\
\text { of ideas, and encourages } \\
\text { individual } \\
\text { accountability for the } \\
\text { successful completion } \\
\text { of the project. }\end{array}$ & $\begin{array}{l}\text { Teacher encourages } \\
\text { teamwork and sharing } \\
\text { of ideas, but doesn't } \\
\text { support individual } \\
\text { accountability of team } \\
\text { members. }\end{array}$ & $\begin{array}{l}\text { Teacher let student } \\
\text { work in teams, but } \\
\text { doesn't encourage } \\
\text { cooperation and } \\
\text { sharing of ideas. }\end{array}$ \\
\hline f. & $\begin{array}{l}\text { Assess- } \\
\text { ments }\end{array}$ & $\begin{array}{l}\text { Teacher monitors } \\
\text { student understanding } \\
\text { through classroom Q\&A } \\
\text { and reviews of } \\
\text { submitted work, and } \\
\text { provides students with } \\
\text { formative feedback. }\end{array}$ & $\begin{array}{l}\text { Teacher monitors } \\
\text { student understanding } \\
\text { through classroom Q\&A } \\
\text { and reviews of } \\
\text { submitted work, but } \\
\text { provides students with } \\
\text { limited feedback. }\end{array}$ & $\begin{array}{l}\text { Teacher rarely } \\
\text { monitors students' } \\
\text { quality of work and } \\
\text { provides limited } \\
\text { formative feedback. }\end{array}$ \\
\hline
\end{tabular}

\section{EfA Units in Light of Participating Teachers' Feedback}

A total of 22 teachers participated in the EfA curriculum development study. In the study, half of the teachers taught the EfA water unit, and the other half taught the food unit. The teachers implemented the new units over an 8-10 week period of time with technology education students in Grades 6-9. After the teachers finished their teaching of the original EfA units (before the revision of the curricular materials), they were asked to express their opinions on the new curriculum by rating various aspects of their experience on a 5-point Likert scale in which 1 is strongly disagree and 5 is strongly agree. Results from this online survey are displayed in Table 6. 
Table 6

Results from the Online Teacher Survey (Prior to Curriculum Revision)

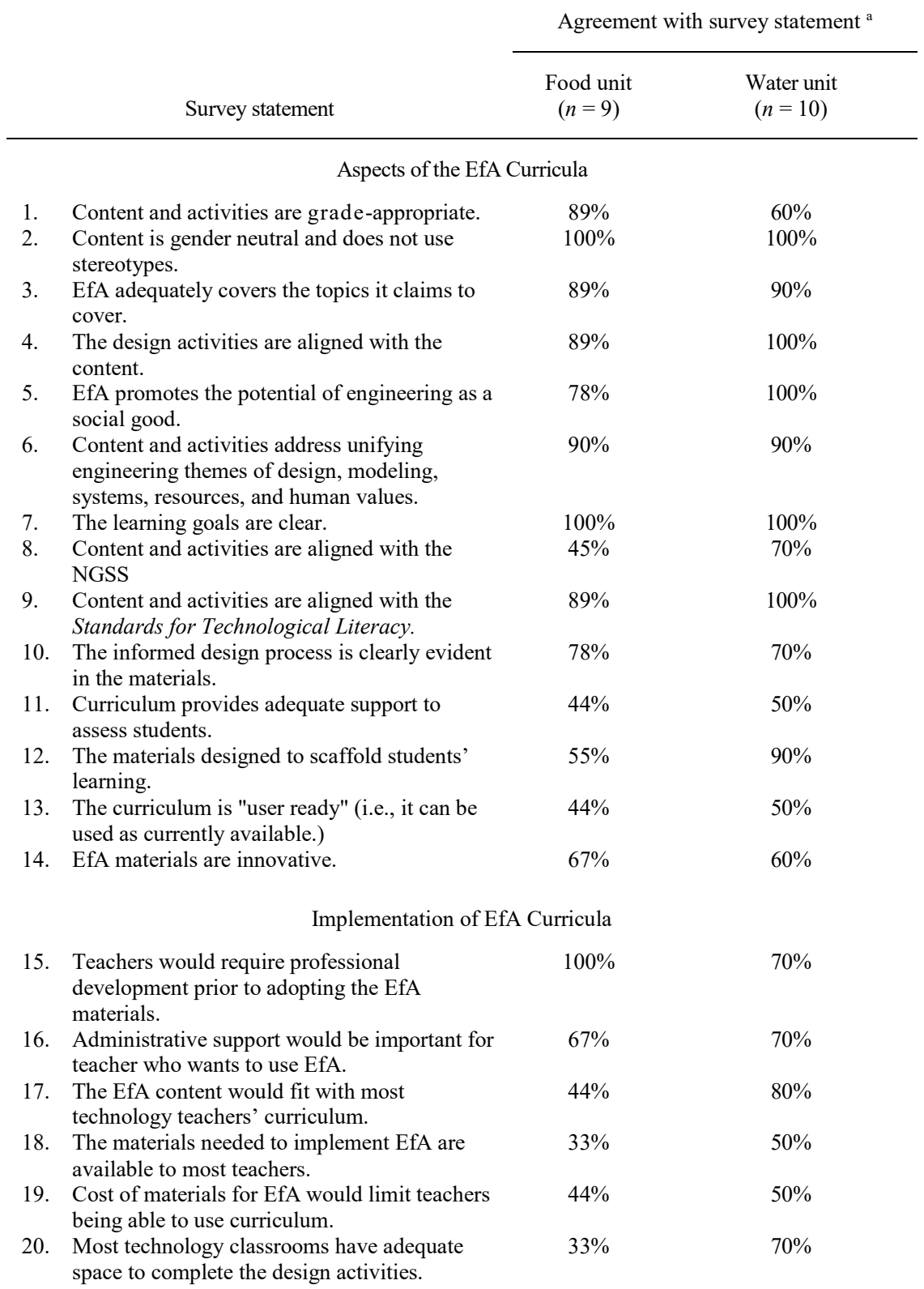




\section{Appropriateness to Students}

\begin{tabular}{|c|c|c|c|}
\hline 21. & $\begin{array}{l}\text { The EfA content was interesting to my } \\
\text { students. }\end{array}$ & $89 \%$ & $70 \%$ \\
\hline 22. & The EfA content was valued by my students. & $78 \%$ & $80 \%$ \\
\hline 23. & $\begin{array}{l}\text { The EfA content was culturally relevant for } \\
\text { my students. }\end{array}$ & $78 \%$ & $80 \%$ \\
\hline 24. & My students had the needed pre-knowledge. & $11 \%$ & $30 \%$ \\
\hline 25 . & $\begin{array}{l}\text { Social issues discussed in EfA are appropriate } \\
\text { for middle school students. }\end{array}$ & $33 \%$ & $70 \%$ \\
\hline
\end{tabular}

${ }^{a}$ Includes the combined responses of agree (4) and strongly agree (5).

The results shown in Table 7 indicate that although most teachers had positive opinions about the new curriculum, they also found that the content of the unit required knowledge that students do not have (Item 24) and that it was above the ability of their students (Item 25). EfA teachers also were concerned about the readiness of the units for classroom instruction and the cost and availability of materials to implement these units on a regular basis (Items 11-13 and Items 17-20). The findings from this online survey, in addition to more detailed information that was gathered through the teachers' portfolio, were used to revise and improve the curriculum.

\section{Findings from Review of Teachers' Portfolios and Implications for EfA Curricular Revisions}

The participating EfA teachers submitted the requested portfolio logs and the three videotaped teaching vignettes while teaching the units. At the conclusion of the units, the teachers submitted student work with teacher annotations as well as personal reflections. Teachers' portfolio materials were submitted electronically via Dropbox or physically via regular mail. At the conclusion of the project all of the written materials were printed and bound and were also rendered as PDF files in order to make the portfolio review more accessible. Three trained researchers reviewed the teacher portfolios individually and then met to compare evaluations and explore patterns found in the data reviewed. Differing interpretations of teachers' performances were resolved through discussion.

The following describes findings from the review of the teaching portfolios and main curricular revisions. Findings are organized by the three dimensions of the design teaching standards and rubrics: Design Practices, Engineering Themes, and Classroom Instruction.

\section{Dimension I: Design Practices}

Review of teacher logs and videos showed that EfA teachers understood the steps of the informed design process and made references to them during instruction. Burghardt and Hacker's (2004) informed design model was introduced in the EfA's introductory materials for students and was used to 
structure the learning activities that students completed to address the Grand Design Challenge found at the end of the unit. Teachers noted that even though the informed design process was introduced to students at the outset of the unit, they had for the most part forgotten and had difficulties recalling and applying this model when addressing the culminating design challenge.

One difficulty that teachers encountered when implementing the first edition of the EfA materials revolved around the use of scientific inquiry during the design process. For example, lessons in which students attempted to design fair-test experiments that explored key factors influencing plant growth in the hydroponics systems that they were building (e.g., the makeup of the nutrient solution, its $\mathrm{pH}$ levels, and lighting conditions) required that EfA teachers be able to explain to students the notion of a controlled experiment, dependent and independent variables - common misconceptions that students have regarding the use of control-of-variables strategy (Schwichow, Croker, Zimmerman, Höffler, \& Härtig, 2016; Klahr \& Nigam, 2004), and ways to measure key outcomes in an experiment effectively. Videos of several EfA teachers conducting lessons in which students designed experiments showed that several were unfamiliar with the practices related to scientific experimentation. Others, who may have known the key elements of good experiments (e.g., Harlen, 2001), did not integrate them into their teaching. Instead of engaging their learners in building a better understanding of scientific inquiry and the practices of designing fair-test experiments, some teachers gave cookbook directions for their students to follow. Thus, their students did not plan their own investigations but rather followed the directions and did the tasks that their teachers gave them. Another set of difficulties that were noted involved the ways in which teachers did or did not help students develop and evaluate several alternative design solutions before letting them move on to building their prototypes. In addition, most of the EfA teachers, perhaps to save time, did not give their students opportunities to revise their prototypes, even when prior tests had revealed flaws in those prototypes.

Based on these findings, the revised units were shortened to include fewer KSB activities prior to the main design activities so that those remaining could be done in more depth before students took on the unit's Grand Design Challenge. In addition, the scientific inquiry was connected more directly to EfA design challenges and better scaffolding, which was done to clarify the essence of the scientific experimental method for both teachers and students.

\section{Dimension II: Understanding the Engineering Themes}

The grasp and depth of teachers' portrayal of EfA engineering themes (i.e., design, models, systems, resources, needs, impacts, and human values) and of working within given constraints when developing and optimizing, were varied. Videos of instruction included in EfA teaching portfolios revealed how some teachers engaged their learners in discussing key themes and addressing 
students' misconceptions. Other EfA teachers did not seem to know ways to engage and elicit students' understanding. These teachers therefore rarely noted and addressed students' shortcomings. In general, teachers did not emphasize the importance of the engineering themes as crosscutting (meaning that these themes are important in multiple design challenges) but rather discussed the themes as they related to the specific design challenge at hand. Although most of the participating technology teachers had difficulties with the concepts and the themes, some teachers revealed a deeper understanding of the EfA concepts. For example, one teacher infused instruction about other types of hydroponics systems in addition to the two systems highlighted in the EfA curriculum. Another teacher added just-in-time instruction on the periodic table when students were learning about types of water chemical contamination.

Based on these findings, the units' revisions focused on clarifying the thematic focus of each subunit and providing more explanations and examples to engage students in explorations of the relevant themes.

\section{Dimension III: Classroom Instruction}

Abundant evidence was found in teachers' portfolios that EfA teachers were capable and effective in the management of their classrooms and their use of general pedagogical skills in engaging students and managing instruction. Teachers were found to use whole-class and small-group settings when presenting and implementing EfA content and activities. They excelled when teaching procedural and practical knowledge relevant to the field of T\&E education, including the appropriate use of tools for making prototypes and use of a computer-aided drawing system, such as Google's Sketchup program that was highlighted in the EfA materials.

However, teachers were lacking when it came to two major components of effective design instruction: understanding essential science concepts and using assessment to support learning. The design challenges in the EfA units had strong links to relevant science concepts. For example, in the food unit, in order to design functional vertical hydroponic urban farms, students needed to understand concepts such as plant physiology and growth, the function and performances of pumps in different hydroponic systems, and concepts related to building stable and strong structures, as with wall-mounted reservoirs or hydroponics growth beds. In the water filtration unit, students needed to understand various concepts related to physical, chemical, and biological sources of water contamination as well as the operation and maintenance of filters that are designed to meet important performance objectives. Most of the participating technology teachers faced challenges in engaging their students in learning these concepts. This shortcoming may be rooted in lack of proper content preparation of the teachers or lack of time to explain the content well.

The second instructional practice that was challenging for teachers was the use of assessment. The EfA predesign activities (e.g., the KSBs) included one 
performance-based assessment task each. Students' work on these assessment tasks were collected and annotated with instructor comments by the teachers as part of their portfolio submission. Teachers' annotations that were written on their student work showed that the EfA teachers are not accustomed to providing meaningful formative feedback to students about the quality of their performance. Most written feedback included praises and encouragements (e.g., "I love your answer," "good work," or illustrated "smiles"). Instances in which teachers overlooked student misconceptions or did not comment on a feature of a design that would not work if built (e.g., a gravity fed filtration system in which the source of water was lower in height than the filter itself) were also noted. In general, there was a high correlation between teachers' conceptual understanding and the quality of their feedback to students: Teachers who understood the units' science concepts well were able to provide appropriate feedback, and teachers who lacked familiarity with the design and science concepts provided only limited formative feedback to their students.

Based on these findings, the revised EfA units included content-based support materials for the teachers to strengthen their understanding of the relevant science. In addition, every KSB included one major performance task (e.g., drawing a model, providing explanations, reporting experimental data, or creating concept maps) and content-specific rubrics for the evaluation of student work on each task.

\section{Use of Teaching Portfolios for Professional Development}

At the start of the EfA project, the exposure of the teachers to the design teaching standards and the accompanying rubrics was limited because these materials were developed later in the life of the project; in fact, they occurred hand-in-hand with the review of the portfolios. However, the project's materials were used extensively later in the preparation of additional EfA teachers during professional development workshops. For example, during the 2017 ITEE conference, the project introduced the EfA units and used materials from submitted portfolios (e.g., video clips and annotated student work) to train prospective EfA technology teachers.

Teaching portfolios can also provide contexts for peer coaching and mentoring in which teachers analyze their own and others' classroom work via the portfolios that they create. A recent study of Harvard's Best Foot Forward program, a video-based teacher evaluation system, showed improved instruction as a result of peer review of shared videos (Quinn, Kane, Greenberg, \& Thal, 2015).

\section{Conclusions}

In our EfA research, we found that the design teaching standards and rubrics were extremely useful in evaluating curricula under development and the learning opportunities they provide to students, similar to findings about the use 
of science content standards in evaluating published curricula in previous research (Kesidou \& Roseman, 2002).

The teaching portfolios were found to be a rich and useful instrument for collecting and reviewing data about the ways in which the participating T\&E teachers implemented the new EfA curriculum. In general, teachers see the portfolio development as an extra instructional load and would probably not develop portfolios on their own. However, if trained and paid for the effort, teachers will develop authentic teaching portfolios that can serve as an efficient substitute for actual classroom observations. The EfA teaching portfolios developed in this project were not intended to be evaluative measures of teacher performance; however, they provided valuable evidence and directed the necessary curriculum revision and changes. In addition, the teaching portfolios opened windows into the common instructional practices of middle school T\&E teachers and increased our understanding of the needed professional development to improve current T\&E instruction.

The standards and the accompanying rubrics that were developed in the project can be used for teachers' self-assessment as well as for professional development purposes. Because the standards and the rubrics are not content specific, they can be adapted and used with a wide range of engineering designbased K-12 STEM curricula. Providing teachers with teaching standards and performance rubrics can guide and improve instruction in T\&E settings.

\section{References}

Ball, D. L., Lubienski, S., \& Mewborn, D. (2001). Research on teaching mathematics: The unsolved problem of teachers' mathematical knowledge. In V. Richardson (Ed.), Handbook of research on teaching (4th ed., pp. 433-456) New York, NY: Macmillan.

Buelin, J., Clark, A. C., \& Ernst, J. V. (2016). Engineering's grand challenges: Priorities and integration recommendations for technology education curriculum development. Journal of Technology Education, 28(1), 37-52. doi:10.21061/jte.v28i1.a.3

Burghardt, M. D., \& Hacker, M. (2004). Informed design: A contemporary approach to design pedagogy as the core process in technology. The Technology Teacher, 64(1), 6-8.

Crismond, D. P., \& Adams, R. S. (2012). The informed design teaching and learning matrix. Journal of Engineering Education, 101(4), 738-797. doi:10.1002/j.2168-9830.2012.tb01127.x

Cross, N. (2000). Engineering design methods: Strategies for product design (3rd ed.). New York, NY: Wiley.

Darling-Hammond, L. (1999). Reshaping teaching policy, preparation, and practice: Influences of the National Board for Professional Teaching Standards. Washington, DC: AACTE Publications.

Design and Technology Association. (2003). Minimum competences for trainees 
to teach design and technology in secondary schools (Research Paper No. 4). Warwickshire, United Kingdom: Author.

Farmer, C., Klein-Gardner, S., \& Nadelson, L. (2014). Standards for

preparation and professional development for teachers of engineering.

Washington, DC: American Society for Engineering Education. Retrieved from https://www.asee.org/documents/papers-and-

publications/papers/outreach/Standards_for_Preparation_and_Professional Development.pdf

Hacker, M. (2014). Key engineering and technology concepts and skills for the general education of all high school students in the United States: A comparison of perceptions of academic engineering educators and high school classroom technology teachers (Doctoral dissertation). Ben-Gurion University of the Negev, Beersheva, Israel.

Harlen, W. (with Elstgeest, J., \& Jelly, S.). (2001). Primary science: Taking the plunge. Portsmouth, NH: Heinemann.

Kesidou. S., \& Roseman, J. E. (2002). How well do middle school science programs measure up? Findings from Project 2061's curriculum review. Journal of Research in Science Teaching, 39(6), 522-549. doi:10.1002/tea. 10035

Klahr, D., \& Nigam, M. (2004). The equivalence of learning paths in early science instruction: Effects of direct instruction and discovery learning. Psychological Science 15(10), 661-667.

Lomask, M. S., Pecheone, R. L., \& Baron J. B. (1995). Assessing new science teachers. Educational Leadership, 52(6), 62-65.

Magnusson, S., Krajcik, J., \& Borko, H. (1999). Nature, sources, and development of pedagogical content knowledge for science teaching. In J. Gess-Newsome \& N. G. Lederman (Eds.), Examining pedagogical content knowledge (pp. 95-132). Dordrecht, the Netherlands: Kluwer.

National Academy of Science. (2017). NAE Grand Challenges for Engineering ${ }^{\mathrm{TM}}$. Washington, DC: National Academies Press. Downloaded on April 21, 2018, from:

http://www.engineeringchallenges.org/File.aspx?id=11574\&v=34765dff

National Research Council. (1996). National science education standards. Washington, DC: National Academy Press. doi:10.17226/4962

Quinn, D. M., Kane, T., Greenberg, M., \& Thal, D. (2015). Effects of a videobased teacher observation program on the de-privatization of instruction: Evidence from a randomized experiment. Cambridge, MA: Center for Education Policy Research, Harvard Graduate School of Education. Retrieved from http://cepr.harvard.edu/files/cepr/files/12a_de-privatizationof-instruction.pdf

Reimers, J. E., Farmer, C. L., \& Klein-Gardner, S. S. (2015). An introduction to the standards for preparation and professional development for teachers of engineering. Journal of Pre-College Engineering Education Research, 5(1), 
40-60. doi:10.7771/2157-9288.1107

Sato, M. (2014). What is the underlying conception of teaching of the edTPA? Journal of Teacher Education, 65(5), 421-434. doi: $10.1177 / 0022487114542518$

Schwichow, M, Croker, S., Zimmerman, C., Höffler, T., \& Härtig, H. (2016). Teaching the control-of-variables strategy: A meta-analysis. Developmental Review, 39, 37-63. doi:10.1016/j.dr.2015.12.001

Shulman, L. S. (1986). Those who can understand: Knowledge growth in teaching. Educational Researcher, 15(2), 4-14. doi:10.3102/0013189X015002004

Wolf, K. (1996). Developing an effective teaching portfolio. Educational Leadership, 53(6), 34-37.

\section{About the Authors}

Michal Lomask (michalomask@gmail.com) is Principal of the ETGaR Center for Science Education and former Connecticut State Education Department Supervisor for Science Education and Assessment.

David Crismond (dcrsimond@ccny.cuny.edu) is an Associate Professor at the School of Education, City College of New York, and holds a courtesy faculty appointment with the Grove School of Engineering.

Michael Hacker (michael.hacker@hofstra.edu) is Co-Director of the Center for STEM Research at Hofstra University in New York. 